\title{
Evaluating Students' Personality and Learning Styles in Higher Education: Pedagogical Considerations
}

\author{
Afzaal, Seyal', Noor Zainah Siau and Wida Susanty Hj. Suhali \\ School of Computing \& Informatics, \\ Universiti Teknologi Brunei. \\ Brunei Darussalam
}

\begin{abstract}
The study investigates the relationship between students' personality traits and learning styles in an institution of higher learning in Brunei Darussalam. A quantitative survey, based on a random sampling approach was used to conduct the study. Questionnaires from ninety respondents were received and analysed using Chi-square test. Big-Five (OCEAN) personality theory and VARK learning styles were used to study the dominant personality trait and learning style. The results show that openness and agreeableness was the dominant personality trait. In addition, the extraversion personality trait has no relationship with any of the learning styles. On the other hand, a strong correlation exists between both openness to experience and the agreeableness personality trait with kinaesthetic learning style that further suggests that students who are more open and accept discussions are ready to learn when it involves teaching/learning based on a hands-on practical approach and as such learn by doing. Similarly, students with a conscientiousness personality have reading as their dominant learning style. Finally, the relationship between neuroticism and visual learning style are significant. Knowing students' learning style further helps educators to develop an effective teaching/ learning style as a rewarding one other than focusing on the traditional classroom environment.
\end{abstract}

Keywords: Personality Style; Learning Style; Effective Teaching-Learning; Brunei.

\section{Introduction}

In today's competitive academic environments, institutions of higher learning (IHL) are striving hard to put their name high in the world's universities ranking system based on delivering quality teaching-learning and research. Coping with

${ }^{1}$ Corresponding author: afzaal.seyal@utb.edu.bn 
their strategic focus area, most universities around the globe are facing several educational challenges. One of the biggest challenges includes improving deliverables with better teaching-learning facilities and to develop state-of-art pedagogies that foster effective and efficient learning among students. Experts at teaching-learning centers of these IHLs are developing various pedagogies to enhance deliverables for competitive advantage.

Pedagogy is defined as the art of teaching that focuses on as how knowledge and skills are imparted in educational setting. In order to promote conducive teaching/learning the educator needs to develop strategies that are flexible, understand the subject matter deeply, address misconceptions and relate ideas to one another. Knowing several kinds of knowledge about learning is needed by the educator. The educator needs to think about what it means to learn different kinds of material for different situations and how to decide what kinds of learning are most necessary in different contexts. To accomplish various goals and for evaluating a student's knowledge and assessing the student's approach to learning, different kinds of strategies must be used by the educator. In the process of teaching-learning educators must focus on devising approaches that facilitate the learning process by finding an answer as to how learners learn best. It is understood that learning is done not only in groups but also by working individually. Each individual learns according to his own learning style. Thus, individual differences make the learning process more facilitating and rewarding. Identifying the strengths of different learners and investigating their weakness further drives educators to develop and promote pedagogy that values effective teaching and learning.

The research linking personality and learning style among students in academia is not a new phenomenon. Earlier researchers, such as Strelau (1988) predicted that an individual's style and traits manifest themselves as behaviours. Schmechk, $(1983,1988)$ and Schmit and Rayan,(1993) concluded that personality traits are expressed in learning style and learning style are reflected in learning strategies that in turn produce acceptable outcomes. Eysenck, (1998) discovered that successful university students scored low on extraversion and low on neuroticism. Similarly, Rocklin (1994) argued that openness to experience is positively related to students' performance. Based on these assertions this study is purposely conducted to investigate and to understand the student's personality and learning style among students from an IHL and to examine the relationship between them.

Sadeghi et al. (2012) looked for a relationship between personality types and/or traits of learners and the way they employ their learning styles and their academic success in school and university. Depending on the learner personality type it is expected that there will be different leaning styles or preferences which-in turn-affect their learning performance. Learning styles do have an impact on overall student success (Kruck et al. 2014) and active learners have better performance than reflective learners. That is to say, those who actively try things out have higher grades than those who think things out. 


\begin{abstract}
"Within the context of Brunei Darussalam, Seyal et al. (2015) in their preliminary study investigated the relationship between learning style and students' performance in a programming module. The data were collected from a cohort of students who appeared for their first-year examination in a programming concept module and were given the Kolb inventory of learning style. Results indicated that students with converging and assimilating learning styles are closely associated with their pass or credit grade. Similarly, in another Brunei-based study to augment the dominant learning style, Seyal and Rahman (2015) found kinaesthetic remains the major learning styles of the students intending to use the learning management system".
\end{abstract}

As mentioned earlier, the literature reports studies that used various learning styles inventories. The main reason of selecting the VARK is having the advantages of using the VARK model (Fleming and Mills, 1992) in that both students and teachers can adjust their behavior to use model preferences actively and positively in teaching/learning. This learning style is considered as one of the classical learning theories in the educational field and it is a simple to report. It is based on the student receiving vision, hearing and touch. In this study, the students were asked about the way they receive the information and how to best use it in the educational field. People learn and process information in different ways and styles. For decades, education researches designed models to help differentiate how people learn. In this study, the researches use the personality Big-five method and the VARK learning style to collect the students' responses by using a traditional pen and pencil questionnaire method. Our study examines the relationship of the student's personality with their learning style performance by using the Big-five traits. So, it is better to provide some details about these two factors. The personality big five traits of McCrae and Costa, (1987) consist of openness to experience, conscientiousness, extraversion, agreeableness and neuroticism (OCEAN) The detail is presented in Table 1 as below.

Table 1: Personality Traits (McCrae \& Costa, 1987)

\begin{tabular}{lll}
\hline \multicolumn{1}{c}{$\begin{array}{c}\text { Personality } \\
\text { Factors }\end{array}$} & \multicolumn{1}{c}{ Description } & \multicolumn{1}{c}{ Traits } \\
\hline Openness & $\begin{array}{l}\text { Individuals that enjoy new experiences and } \\
\text { learning new things. (Openness to culture) } \\
\text { and able to think abstractly in ways not } \\
\text { directly related to their experiences. }\end{array}$ & $\begin{array}{l}\text { Original, } \\
\text { imaginative, } \\
\text { adventurous, } \\
\text { idealistic and } \\
\text { enthuastic. }\end{array}$ \\
Conscientiousness & $\begin{array}{ll}\text { Individuals control direct and regulate their } \\
\text { own emotions to work towards goals and } \\
\text { plan effectively and want to achieve high }\end{array}$ & $\begin{array}{l}\text { Organised, } \\
\text { systematic, } \\
\text { hardworking, } \\
\text { reliable, responsible } \\
\text { and self-disciplined. }\end{array}$ \\
& $\begin{array}{l}\text { Individuals that get strong energy from } \\
\text { interacting with other individuals and } \\
\text { external worlds. }\end{array}$ & $\begin{array}{l}\text { sociable, energetic, } \\
\text { friendly, optimistic } \\
\text { and talkative. }\end{array}$
\end{tabular}


Agreeableness
Individuals are able to develop better interpersonal skills, getting along with and bulding up trust with other individuals to ensure social harmony.

Individuals are described as being vulnerable to experience with one or more negative feelings and effects from stress and known as emotional stability
Trusting, friendly, cooperative, affectionate, kind and sympathetic

Antagonism, selfrejection, moody, insecure and anxious

Similarly, VARK Learning style (Fleming and Mills, 1992) is divided into four key types: Visual Learners, Auditory Learners, Reading Learners and Kinaesthetic Learners.

Table 2: VARK Learning Styles (Fleming and Mills, 1992)

\begin{tabular}{|c|c|}
\hline $\begin{array}{l}\text { Learning } \\
\text { Style }\end{array}$ & Characteristics \\
\hline Visual & $\begin{array}{l}\text { A visual learner is described best as learning by seeing graphic } \\
\text { displays, such as videos, illustrations and charts. }\end{array}$ \\
\hline Aural & $\begin{array}{l}\text { Aural Learners are best described as hearing information and } \\
\text { good at remembering things that have being told to them. }\end{array}$ \\
\hline Reading & $\begin{array}{l}\text { Reading learners are best described in terms of text-based } \\
\text { learning materials (reading book or e-book) and prefer to jot } \\
\text { down information displayed as words. }\end{array}$ \\
\hline Kinaesthetic & $\begin{array}{l}\text { Kinaesthetic learners are best described as learning by touching } \\
\text { and doing, i.e., hands on experiences. }\end{array}$ \\
\hline
\end{tabular}

Within the context of HLIs literature provides many studies that exclusively focused on the learning styles and Big-five personality inventory among students related to their "cognitive style, academic performance and on the gender differences across the globe". However, little research has been done within the context of South-east Asia. To our knowledge no study has been undertaken in Brunei Darussalam exclusively to understand the relationship between learning style and personality type. Therefore, this pioneering quantitative study concentrates on finding the relationship between students' personality styles and learning styles among higher learning institution in Brunei Darussalam. By understanding the given relationship - ease of learning and teaching can be promoted in a lecture, such that "the biggest effects on student learning occur when teachers become learners of their own teaching, and when students become their own teachers" (Hattie, 2009).

The study used the Big Five personality theory to investigate the student's personality traits and the VARK model to investigate the student's learning style preference. The VARK model can be used for the students to develop their own learning method with which they are conformable with and to perform at their own pace of understanding (Othman and Amiruddin (2010). Any method in the VARK learning style, students can use to attain new knowledge and it can help students to stimulate a positive and challenging learning environment. Therefore, in some situations this approach might give the students more enjoyment in learning. In addition, by achieving the study's objective through data collection as outlined in the methodology and results sections, we would be 
able to describe an academic approach that would help in the learning and teaching process for both students and lecturers of the university.

Based on the above discussion, this study was conducted with the following objectives: 1) to assess the most common learning style and personality traits among the Bruneian students. 2) To discuss the relationship between student's personality traits and student's learning style. 3) To apply the result of the study in designing effective teaching and learning pedagogy among university's students.

\section{Review of Previous Studies}

Personality and Learning Style: - Since the purpose of this study is to investigate the correlation between personality traits and learning style, we focus on reviewing specifically those studies which explored this relationship. Before going further into in-depth analysis, we would like to add that while discussing personality two terms, "types" and "traits" although measuring different dimensions, have been used interchangeably (Sadeghi et al. 2012) and convey the similar meaning to keep the context simple.

A review of the literature provides a rich source of studies that explored the relationship between students' personality and learning style to influence educational outcomes especially in academic performance and to predict school examination results (Chamorro-Premuzic and Furnham, 2008; Furnham, Monsen and Ahmetoglu, 2009; Komarraju et al. 2011; Stojanovska et al. 2015; Marcela, 2015). Furnham (1992) in his early work reported three studies correlating personality with learning style using the Honey and Mumford (1992) learning style questionnaire; the Whettsen and Cameron, (1984) cognitive style inventory and the Kolb (1984) learning style inventory. He found that in each case the personality measure of extraversion and psychoticism were relatively strongly co-related with learning style. Komarraju et al. (2011) conducted a study among 308 undergraduates to test the relationship between personality and learning styles. They found that "conscientiousness and agreeableness have a positive relationship with all types of learning styles". On the contrary, the personality trait "neuroticism" has an inverse relationship with the learning style-VARK. Sadeghi et al. (2012) conducted a study to highlight the relationship between learning style, personality and reading comprehension performance. Salehi et al. (2014) studied the effect of personality characteristics on the learning styles of the student and suggested positive associations with learning style. $\mathrm{Wu}$ and Lai (2010) conducted cross cultural study on the learning style and personality type among the undergraduate students in Taiwan and in United States. Results indicated relationship existed with slight variations between two countries. Taiwanese participants have stronger relationships than US participants.

Busato et al. (1998), in their early study, found a positive relationship between extroversion and diverging and accommodating leadership style. Nevertheless, the majority of the studies identified different learning styles and approaches but comparatively few, to our knowledge, have used the VARK learning style and identified the relationship with Big-five personality type. Threeton and 
Walter (2009) conducted a study among Automotive Technology Students in USA to identify the relationship between personality and learning style. They suggested that a majority of the participants had predominantly Realistic Personality classification and identified the relationship between personality and learning style. On the other hand, Kamarulzam (2012), in Malaysia reviewed the effect of personality on learning style by using the Big-five factor model of personality against Kolb learning style. He concluded that personality does have an effect towards learning style. Siaw, Jagmohni, and Ankur, (2015) studied 419 undergraduate medical students in Malaysia to identify the learning styles of the medical students and found that the most significant learning style was kinaesthetic, and no relationship could be found between study approach and study style. In another study, Nzesei (2015) found that the majority of the students possess trimodal learning style such as: Visual, Aural and Kinaesthetic learning style and confirmed the existence of significant relationship between academic achievements and learning styles of the responding students.

Bazier (2015), conducted a study of 302 college students in Texas, United States to investigate the relationship between instructor's level of extraversion and student's learning modalities in a community college setting and found that extraversion of the instructors and students' visual, learning style are related $(\mathrm{P}<0.05)$. However, auditory and kinaesthetic learning styles are negatively related with extraversion personality trait of the instructors.

Similarly, Moorman and Clark (2012) found that extraverted personalities are more related to auditory and visual learning style. On the other hand, the personality type "agreeableness" is significantly related to auditory, tactile and visual learning. Personality type "openness" is significantly related with auditory and visual learning styles. Personality type "conscientiousness" is significantly related to auditory, tactile and visual learning styles. "Neuroticism" is negatively related to both auditory and tactile learning style.

Urval et al. (2014),conducted a study among 415 undergraduate medical students in Karnataka, India to describe the learning styles of the participating undergraduate medical students where the students are mostly multimodal learners, whereby, according to VARK - most students prefer quadmodal (more than one learning modalities). Aural (auditory) and kinaesthetic are the most preferred learning modalities while gender and academic performance (marks) are rather insignificant and have no correlation with learning styles. In another study conducted by Erdal et al. (2014), 46\% out of 224 participants adopted assimilating learning styles. Assimilator people are said to be interested in ideas and concepts; most of the participants have agreeableness trait but the researchers could not find any significant correlation between personality traits and learning styles.

Hakimi, Elaheh and Masoud (2011) found conscientiousness was the main predictor of academic achievement and emphasised that it is necessary to inform curriculum developers of the personality traits and individual differences of learners. They found that there were no significant differences among male and female participants in personality traits. In a study conducted by Komarraju et al. (2011), the trait of openness acts as main role in student progress, while the 
learning style of reflective has a relationship with the students' results' in their GPA. Thus, students who are highly curious were able to relate what they had learned to a real life situation and they were also able to organise the information in a way that it matches with their preferences in learning style that can help them, systematically organise their study so that they can excel in their examination.

Shahri et al. (2012) examined the relationship between learning styles and personality dimensions of obsessive-compulsive disorder among 150 undergraduate students. Results showed that the divergent learning styles (watch) tends towards extroversion whereas convergent learning styles (think \& do) are related significantly with introversion.

Ghyasi, Yazdani and Farsani (2013) examined the relationship between personality types and self-regulated learning strategies of language learners among 231 undergraduate students of English in Iran. They found that the relationship between personality type and self-regulated learning strategies does exist and that the person's personality is important and also act as a foundation on learning strategies as well. Kharb et al., (2013) determined the preferred learning style of first year medical students in India, found that the majority of the students had multimodal learning styles and 39\% preferred a kinaesthetic style and the least preferred style was reading/writing (12\%). Lin and Armstrong (2015) tested the relationship between Kolb's experiential learning styles and Big-five personality traits in 269 international managers and found that extraverted managers have a preference by engaging in concrete experience and tend to have an accommodative learning style.

Similarly, Yanardoner et al. (2014) conducted a study to investigate the relationship between dominant learning styles and personality traits among students. The result indicated that "majority of the students had an assimilator learning style and the most frequent personality trait was agreeableness". Rashid et al. (2012) studied learning style and personality traits among students in Malaysia and tested the relationship by using electroencephalogram (EEG) and found that assimilator learning style correlated with the agreeableness personality trait. Similar results were found in a study that was conducted in Istanbul, Turkey (Kiziltepe, 2014). The results showed that "assimilator" and "agreeableness" emerged as most common learning as well personality trait of the respondents. The study could not support the relationship between personality traits and learning style with mediating gender remained insignificant.

Khan et al. (2018) in their Malaysian based study on the effect of personality traits and learning style towards students' academic achievement further revealed that most common personality traits were openness and conscientiousness. While more common learning style was noticed as converger (thinker \& doing) on Kolb topology. The study could not establish a relationship among personality, learning style and academic achievement. In addition, gender remained as insignificant with personality traits and learning style. In another study of 144 university students, Siddiquei and Khalid (2018) found that 
extraversion personality trait was positively related with all four-learning style. However, neuroticism was negatively related with all four-learning style. They also could not establish a relationship between personality traits, learning styles on the basis of gender.

It is evident from the above studies that 1) research on personality and learning style are not confined to one particular learning style or personality types rather it is classified and further diversified to various measuring instruments that has produced in consistency in the research and literature reports on the research gap (Furnham, 1992; Poropat, 2009). Therefore, there is a strong need, not only to conduct the studies using various measuring instruments but also to test the students' population among multi-disciplinary environments across the globe so as to add the knowledge from multiple sources. 2) Like any other research endeavours the research on learning style especially do not provide an answer in absolute terms. There is evidence, on the contrary, that respondents do try to treat tasks according to their learning style but it does not help them to attain an overall success. Similarly the notion that teaching methods should match with students' particularly learning style have exerted a powerful influence on education for the past thirty years, however, there is a "Big? " as scientific research on learning style till date provide scant information to test the hypotheses that people learn better when taught in a way that matches their learning style. To get it answer, research should provide with more supporting evidence (www.scientificamerican.com/article/the-problem-with-learningstyle).

Conclusively, the review of literature exhibits discrepancies and variations in findings that lead to literature gap. This further suggest to conduct more studies and to get more empirical evidences by adding various variables and dimensions to fill-in the research gap. This study therefore is conducted to fill-in the research gap that might provide a new finding and to add the existing knowledge.

\section{Research Methodology}

In this study, a questionnaire was chosen as a design tool to collect information from an individual. This kind of questionnaire needs the participant to respond by selecting the answer options that have been provided. The questionnaires were distributed in hardcopy format to 100 undergraduate students.

\section{Questionnaire Design}

The research instrument used in this study is divided into three parts. Part A collected information on students' demographical data, such as the participant's gender, which age group they belong to, participant's educational qualification and what subject area they are in. For part B the emphasis is on collecting personality data from the Big Five (OCEAN) where O stands for Openness, C stands for Conscientious, E stands for Extraverted, A stands for agreeable and $\mathrm{N}$ stands for Neurotic. There were 20 questions in this section and it used a Likert scale starting from1, strongly disagree, 2 somewhat disagree to 3 neither disagree nor not disagree, 4 agree to some extent and 5 strongly agree; where the 
participant responds to the statement by writing down the number. Part $\mathrm{C}$ focuses on Learning Style (VARK) which has 16 questions where the participants choose ones that best apply to them: V stands for Visual; A stands for Audio, $\mathrm{R}$ and $\mathrm{K}$ are for Reading and Kinaesthetic, respectively. The main advantage of the VARK model preferences is that both students and teachers can adjust their behaviour to use model preferences positively in teaching and learning.

\section{Participants}

The total sample of participants in this study consists of 100 undergraduate students of a technical university in Brunei. They were selected randomly under the convenience sampling techniques for the three faculties. Out of 100, ten subjects were dropped because of non-response errors. These students are categorised by gender, age group of 15 to 19, 20-25 and above 25, education qualification as either HND or 1st Degree and subject area in terms of Computing \& IT, Business and Engineering.

\section{Validity of the instrument}

A research study to test the validity of VARK for measuring learning style preferences was conducted by Leite, Svinicki and Shi, (2010). Their study shows that a correlated trait- correlated method has the best fit to the VARK score. The estimated reliability of the coefficient was adequate. The study found preliminary support for the validity of the VARK scores (http://varklearn.com/category/news). The reliability was assessed based on confirmatory factor analysis. A further report (http://vark-learn.com/category/news/) shows that a majority of the computing students (3767) have used this instrument out of 27591 university students. Roughly, 34,187 students are from age group between 18-25. Students, by large, have a kinaesthetic learning style $(28 \%)$, followed by Reading (24\%), Auditory (20\%) and Visual (23\%). Nevertheless the reliability of the personality inventory is within the range of .67 to .82 as shown in Table 5. Our results support the report and believe that question of validity is properly assessed.

\section{Analysis of Data and Results}

The data collected in this study were analysed by using descriptive statistics, Chi-square test and correlation test by using SPSS software version 20. Table 3 shows the demographical data found in this questionnaire. $57 \%$ of the respondents are male compared to the females' respondents. The second variable age shows that $50 \%$ respondents are above 25 years. $74 \%$ of the respondents are $1^{\text {st }}$ Degree undergraduates and $94 \%$ respondents are from Computing and IT area. 
Table 3: Students' Demographical Data

\begin{tabular}{lll}
\hline Variable & Descriptions & Percentage \\
\hline Gender & Male & $57 \%$ \\
& Female & $43 \%$ \\
Age & $15-19$ & $4 \%$ \\
\multirow{5}{*}{ Educational Qualifications } & $20-25$ & $46 \%$ \\
& Above 25 & $50 \%$ \\
& HND & $26 \%$ \\
Subject Area & $1^{\text {st }}$ Degree & $74 \%$ \\
& Computing \& IT & $94 \%$ \\
& Business & $3 \%$ \\
& Engineering & $3 \%$ \\
\hline
\end{tabular}

Table 4: Descriptive Statistics of Learning Style Cohort of Students' main learning style

\begin{tabular}{lcc}
\hline Variable & Mean & No of Participants \\
\hline Visual Learning Style & 2.95 & $12.5 \%$ \\
Audio Learning Style & 3.00 & $18 \%$ \\
Reading Learning Style & 3.25 & $32 \%$ \\
Kinaesthetic Learning Style & 3.30 & $42 \%$ \\
\hline
\end{tabular}

Table 4 summarizes the students' overall learning styles in all four categories. In this study, it is seen that the predominant learning styles are Kinaesthetic (Doing) and Reading comparative to Audio (Listening) and Visual. From the above table one can see that most students prefer both kinaesthetic and reading learning style. For visual and audio learning style the percentage is also slightly high as the frequency is above $10 \%$.

Table 5: Descriptive Statistics of Students' Personality

\begin{tabular}{lccc}
\hline \multicolumn{1}{c}{ Variable } & Mean & $\begin{array}{c}\text { No of } \\
\text { participants }\end{array}$ & $\begin{array}{c}\text { Reliability } \\
\text { (a-alpha) }\end{array}$ \\
\hline Openness & 3.56 & $68 \%$ & .81 \\
Conscientiousness & 3.60 & $71 \%$ & .80 \\
Extraversion & 3.15 & $51 \%$ & .77 \\
Agreeableness & 3.74 & $85 \%$ & .73 \\
Neuroticism & 3.23 & $54 \%$ & .67 \\
\hline
\end{tabular}

Table 5 shows the mean and percentage of students in each category of personality on the Big- five. The mean of the results shows that, trait agreeableness has the highest frequency followed by conscientiousness for the students' personality traits. In this study, the students with dominant agreeableness personality trait are open minded, cooperative and trust other individuals; it also shows that the students are studious, have self-discipline and are responsible. As can be seen in the table above, the majority of the respondents possess agreeableness followed by conscientiousness and openness. Interestingly, equal numbers of students fall into the extraversion and neuroticism categories. 
As for the learning style, the students mainly favour kinaesthetic as shown in Table 4. It shows that the students are more into doing, such as hands on practical and prefer to learn new things related to hands on. The second most preferable learning style is reading where the students prefer to read and study materials from a book or e-book. They also prefer to jot down notes and read their notes afterwards. For the audio and visual learning style the mean is quite low compared to the other learning styles (reading and kinaesthetic).

Table 6: Correlation between personality types \& learning styles

\begin{tabular}{ccccc}
\hline Personality type/Learning style & Audio & Visual & Reading & Kinaesthetic \\
\hline Openness & .180 & $.029^{*}$ & .504 & $.031^{*}$ \\
Conscientiousness & .323 & .062 & $.041^{*}$ & .345 \\
Extraversion & .252 & .723 & .765 & .682 \\
Agreeableness & .661 & .683 & .275 & $.028^{*}$ \\
Neuroticism & .494 & $.034^{*}$ & .368 & .390 \\
\hline
\end{tabular}

(In above only $p$-value is given, the asterisk shows $p$ is significant $P=<0.05$ )

The Table 6 as above illustrates the correlation between personality types and learning style. The asterisk shows the significant $p$-value that is less than 0.05 .

The data was analysed using the non-parametric statistical test of Chi Square test because of the nature of our data (ordinal scale) and found that there is a relationship between personality style and student learning style. Table 7 illustrates the relationship tested with Chi-square statistics. A conscientious personality type is related with the reading learning style. Agreeableness and openness are significantly related with the kinaesthetic learning style. As for the neuroticism, the visual style remains as the dominant learning style.

Table 7: Result of Chi-square test to test the relationship

\begin{tabular}{ccc}
\hline Relationship tested & $\begin{array}{c}\text { Chi-square test } \\
\text { statistics }\end{array}$ & Remarks \\
\hline $\begin{array}{c}\text { Extroverted personality type with learning } \\
\text { style }\end{array}$ & $\mathrm{P}>0.05$ & No-significant \\
$\begin{array}{c}\text { Openness personality type with kinaesthetic } \\
\text { and visual learning style }\end{array}$ & $\mathrm{P}<0.05$ & Significant \\
$\begin{array}{c}\text { Conscientiousness personality type with } \\
\text { reading learning style }\end{array}$ & $\mathrm{P}<0.05$ & Significant \\
$\begin{array}{c}\text { Agreeableness personality type with } \\
\text { kinaesthetic learning style }\end{array}$ & $\mathrm{P}<0.05$ & Significant \\
$\begin{array}{c}\text { Neuroticism personality type with visual } \\
\text { learning style }\end{array}$ & $\mathrm{P}<0.05$ & Significant \\
\hline
\end{tabular}

\section{Discussion}

The study identified relationships between students' learning style and their personality using the VARK learning style inventory and Big-five personality measure. The study has fulfilled all of its three objectives. The analyzed data have further revealed that the most common learning style of the responding students is kinesthetic. In fact, $42 \%$ of the students believe in a "doing" or "tactile" learning style followed by reading (32\%) and visual $(12.5 \%)$ styles. The results support the previous Brunei-based study (Seyal and Rahman, 2015) that clearly indicated that the kinesthetic learning style remained as one of the 
favorite learning styles of the students. Our results also supported Urval et al. (2014) and Siaw, Jagmolu and Ankur, (2015) who identified found kinesthetic as the most popular learning style among students. The students preferred hands on practical learning strategies. Kinesthetic learners tend to be touchers and feelers and the best methods of testing their knowledge and learning is with fillin the blanks and multiple choice, while the worst type of tests for them are long essay tests. However, our results are in contrast with Ayesha et al. (2011) who reported that $73 \%$ of the respondents had multiple learning styles. Our results provide some useful information, namely that students from computing are more inclined to learn their best when the learning process involves practical aspects in a form of learning by doing. These students rely less on just reading or looking at displays and rather prefer to learn by doing and problem solving. Table 8 compares the results of this study with a previous Brunei-based study and with a VARK report (www.roe11.k12.1/us/GESstaff/Day3/understandingyourlearningstyles.pdf).

The tabled data confirm the kinesthetic learning style remained dominant among the students.

Table 8: Comparison of Learning Style

\begin{tabular}{cccc}
\hline & This Study & $\begin{array}{c}\text { Seyal \& Rahman } \\
(\mathbf{2 0 1 5 )}\end{array}$ & VARK report \\
\hline Visual Learning style & $12.5 \%$ & $12 \%$ & $23 \%$ \\
Auditory Learning style & $18 \%$ & $10 \%$ & $20 \%$ \\
Reading Learning style & $32 \%$ & $10 \%$ & $24 \%$ \\
Kinaesthetic learning & $\mathbf{4 2 \%}$ & $\mathbf{2 8} \%$ & $\mathbf{2 8 \%}$ \\
\hline style & & & \\
\hline
\end{tabular}

In addition, the role of personality was also studied as a second objective. The study's results show that a majority of the students $(85 \%)$ demonstrate the "agreeableness" personality trait, followed by "conscientiousness" (71\%), openness $(68 \%)$, neuroticism $(54 \%)$ and lastly $50 \%$, the extroversion trait. Our results, therefore, support Erdal et al. (2014) who reported that most of their participants have agreeableness traits and are said to be interested in ideas and concepts as they have the tendency to be altruistic, cooperative and trusting.

Our study has also fulfilled the third objective which is to investigate and understand the relationship between students' learning style and personality types. The result further revealed that students learning style and personality type are related with each other. The data that was analyzed using nonparametric Chi-square test found that the agreeableness personality trait is significantly associated with kinesthetic learning style. It is true and quite logical that agreeable individuals have better interpersonal skill-trustworthy to ensure social harmony, so they learn more efficiently when they are provided with an opportunity by doing hands on experience. Our result support previous studies who found that both kinesthetic and agreeableness are strongly related (Ibrahimoglu et al. 2013 and Urval et al., 2014). Interestingly, our results did not find any support for extrovert personality being associated with any of the learning styles. Extroverts in our study could adopt any learning style or are comfortable with all learning styles. In other words, our results are in contrast to 
Moorman and Clark (2012) and Rashid et al., (2012) who found that extravert individuals exhibit more auditory and visual learning styles. It should be noted that Rashid et al., (2012) studied the Big-five of personality with Kolb learning style measure and found a relationship between extroversion and accommodating learner style which is considered akin to kinesthetic. However, our results partially support Bazier, (2015) who found no relationship between extraversion and visual learning style. Our results also do not support Naserieh, (2009) who found that kinesthetic remained as most commonly used learning style and was associated with group learning.

Continuing our discussion, the study found a strong and significant correlation between conscientiousness personality traits with the reading learning style. A student with a conscientious style of personality is the one that is able to control, direct and regulate their own emotions to work towards goals and they also plan effectively to achieve a high level of success to avoid suffering. Therefore, the student is able to control themselves and works very hard to achieve their targets. Reading learning style prefers to read the study materials from their notes, e-book and books. For instance, to achieve a high grade and GPA for their examination, these students are willing to read their notes and write all important things during the revision. They are also well-organised with their schedule. The results support the study made by Ibrahim et al. (2014), who concluded that reading is the best style and is highly correlated to grade point average. The fact that reading is one of the basic ways for the students to gain knowledge is also supported by this study that found that the conscientiousness personality trait style is related to reading comprehension learning style (Sadeghi et al. (2012). Our results further support a prior study made by Hakimi, Elaheh and Masoud (2011), that the conscientiousness trait is related to reading and was the main predictor of academic achievement.

The openness to experience personality trait is associated with visual as well with kinaesthetic learning style. Students that have an openness type of personality enjoy new experiences, learning new things and are able to think abstractly. Students who possess openness and kinaesthetic learning style further illustrate that they are willing to learn new things that involve hands on activities. They are also able to work in a group. This study supports a prior study by Komarraju et al. (2011), namely, that the trait openness and learning style influenced the student's academic achievements. It may be beneficial for students that are knowledgeably curious and open to new ideas to become more aware of their personal preference type of learning and develop more their reflective style of learning. Our results partially support Moorman and Clark, (2012) who reported opennessnes is significantly related to auditory, visual and kinaesthetic learning style.

Although the mean for neurotic is relatively high compared to the extraversion score in Table 3, we found that it is negatively related to any learning style as the neurotic type of personality is associated with individuals that are easily dejected, feel insecure and emotionally unstable. Neuroticism also relates to fear of failure and lack of attentiveness in their studies. Our results support the prior 
study made by Komarraju et al. (2011), neuroticism has a negative relationship with learning style and suggested that students with this personality type are to be expected to disengage from the education process.

Finally, from Table 4, it can be seen that the means for the audio and visual learning style for our respondents are quite low compared to the reading and kinaesthetic learning style. Students these days prefer the lecturers' teaching style in a way that the students may take part in the learning process, by participating in the activities conducted by the lecturers and then writing down any important things that are being learned at the end of the class. This is in contrast to the traditional way of teaching where the lecturers explain in front of the class and the students see and hear the lecture - visualising and listen (audio) to what the lecturer taught in front of the class. However, our results partially support a previous study conducted by Kharb et al. (2013), as kinaesthetic was the most frequent learning style compared to reading as least preferred one.

From the above discussion we can safely deduct that students would become more interested in learning if lecturers/instructors show related knowledge that pave another need and direction for the students, as students are more cooperative in learning if the lectures demonstrate practical benefits and meet their objectives such as applied knowledge that is useful for working in their fields in the future. In addition, the students are well-versed with learning by 'step-by-step' instructions, if they are practical as students tend to follow and practice the given knowledge that would benefit their future endeavours.

The results provide some useful information that our responding students are more inclined to learn their best when the learning process involves practical aspects in a form of learning by doing. The students rely less on just reading or looking at displays and rather prefer to learn by doing and problem solving.

As for the extraversion type of personality, they are comfortable with all learning styles. The students are willing to engage and socialise with other students or work in a group. They also prefer learning in a class and large group discussion. For example, whenever the lecturers give the students tasks involving group tasks, these students are able to engage with other students in the group and able to complete their work within the time given. Extravert students prefer entertaining teachers, (Salehi, 2010) and believe teachers should have a good relationship with their students.

The study also shed some light on the anticipatory educator's personality which in fact was not measured in this study. The educator's personality style also plays a vital role in order to make the study process in the lecture room interesting. Students prefer educators that are easy to communicate with and flexible to approach so that they can discuss and share with them their difficulties and thus create harmony where the teaching learning process can be more rewarding. An introverted educator who is anxious and prefers less interaction is likely to assign their students work based on reading materials and 
assignment and also provide hand-outs. Such lecturers can also use videorecorded lectures (Jalili and Mall-Amiri, 2015) compared to those who possess extraverted personality and employ a discussion type forum to highlight the key points (Shah and Meisenberg, 2012).

\section{Conclusion}

The study has fulfilled all of its three objectives and further demonstrated the usefulness of learning style with the personality in designing the teaching and learning pedagogy for university's students. Interestingly, understanding students' learning style helps educators to select the most effective style of teaching and not only focus on one teaching approach. When the educator's teaching methods match the learning style of the students, the chance for them to learn easily and understand quickly can be advantageous to their university ranking due to high rate of degree achievement. To improve the student's grade and student's interest in the learning process, we suggested that the educator should not focus on one style of teaching. One way to make the teaching style interesting is by designing and using teaching methods based on a hands-on approach that works for students that have a kinaesthetic learning style.

Limitations: No study is complete without mentioning the limitations- so does ours. In fact, when addressed properly these could enhance future research endeavours. The study suffers the inherited problem of survey research, namely, non-response bias. By increasing the sample size and the inclusion of students from various faculties we could perhaps add validity to our findings. The study does not consider the use of multiple learning styles which might be more effective. The study could further be improved by controlling the gender variable which might possibly add some new findings.

Recommendations: Based on the results of this study, we recommend to conduct more studies using different learning style inventories with more independent variables longitudinally and cross culturally in different geographical setting to narrow down the gap that will help us in building more advanced and predictable models that will not only provide but also support an effective pedagogical and endrogogical tools to improve teaching and learning. It is also recommended that a lecturer should devise a balanced pedagogy so that students having different learning styles are benefitted. In this regard, educators should be provided some training, such as, a one-day forum or a workshop on different learning styles of students and how to adapt their teaching approach to the students. By understanding the students' learning styles educators could design both formative and summative assessments that could further make the teaching-learning environments more productive. In addition, the educators should have more interaction with their students to make the learning process interesting. By understanding the cause and effect relationship among students' learning style and their personality types in teaching and learning could further be improved for a high level of performance and productivity among higher learning institutions. Center of Communications of Teaching and Learning (CCTL) could devise various teaching strategies to achieve the results. 


\section{References}

Ayesha, N., Salem, R. O., Quadri, M. S. A., Al-Hamdan, N. (2011). Learning style preferences of medical students: A single institute experience from Saudi Arabia. International Journal of Medical Education, 2: 70-73. https://dx.doi.org/10.5116/ijme.4e36.d31c

Bazier, C. (2015). An analysis of instructor extraversion and student learning style. Unpublished dissertation, Walden University. Retrieved October 1, 2018, from http:/ / scholarworks.waldenu.edu/cgi/viewcontent.cgi?article=1251\&context= dissertations

Busato, V. V., Prins, F. J., Elshout, J. J and Hamaker, C. (1998). Personality traits and achievement motivation in higher education. Personality $\mathcal{E}$ Individual Differences, 26(1), 129-143. https://dx. doi.org/10.1016/s0191-8869 (98)00112-3

Chamorro-Premuzic, T., and Furnham, A. (2008). Personality, intelligence and approaches to learning as predictors of academic performance. Personality and Individual Difference, 44(7), 15961603. https://doi.org/10.1016/j.paid.2008.01.003

Darling-Hammond, L. (1998). Teacher learning that supports student learning.Educational Leadership, 55(5). Retrieved November 1st, 2018 from http://www.ascd.org/publications/educational-

leadership/feb98/vol55/num05/Teacher-Learning-That-Supports-StudentLearning.aspx.

Eicher, J. (1987). Making the Message Clear. Santa Cruz, CA: Grinder, DeLozer \& Associates.

Erdal, Y., Kiziltepe, Z., Seggie, F. N., and Sekerler, S. A. (2014). The Learning styles and personalities traits of undergraduate: A case at a state university in Istanbul. The Anthropologist, 18(2),

$591-$ 600. https://dx.doi.org/10.1080/09720073.2014.11891577

Eysenck, H. J. (1996). Personality and the experimental study of education. European Journal of Personality, 10(5), 427-439. https://dx.doi.org/10.1002/ (sici) 10990984(199612)10:5\%3C427::aid-per254\%3E3.3.co;2-8

Fleming, N. D. (2001). Teaching and Learning Style: VARK Strategies. Christchurch New Zealand: N.D. Fleming.

Fleming, N. D., and Mills, C. (1992). VARK a guide to learning style. (http://www.vark.learn.com/English?index.asp).

Furnham, A. (1992.) Personality and learning style: A study of three instruments. Personality and Individual Difference, 13(4), 429-438. https://dx. doi.org/10.1016/0191-8869 (92)90071-v

Furnham, A., Monsen, J., Ahmetoglu, G. (2009). Typical intellectual engagement, Big-five personality traits, approaches to learning and cognitive ability predictors of academic performance. British Journal of Educational Psychology, 79(4), 769782. https://dx.doi.org/10.1348/978185409x412147

Ghyasi, M., Yazdani, M., Farsani, A. B. (2013). The relationship between personality types and self-regulated learning strategies of language learners. International Journal of Applied Linguistic and English Literature, 2(4), 74-82.

Hakimi S. , Elahah H., \& Masoud G. L. (2011). The relationships between personality traits and students' academic achievement.Procedia-Social and Behavioral Science, 29, 836-845. doi: 10.1016/j.sbspro.2011.11.312

Halpin M. (2014). The Big-five aspects of personality. Retrieved September 18, 2018, from Apple Tree: http:/ / www.appletreehealthandwellness.com/the-big-5-aspects-ofpersonality/ 
Hattie, J. (2009). Visible learning: A synthesis of over 800 meta-analyses relating to achievement. Abingdon, Oxon: Routledge.

Honey, P., and Mumford, A. (1992). The Manual of Learning Style (Revised Version). Maidenhead: Peter Honey.

Ibrahim, N.S., Yusof, C. N. S. H., Razak, N. A., Norshahidi, N. D. (2014). A meta-analysis of the relationship between big five personality traits and students' academic achievement. ICSSR-e-Journal of Social Science Research, 1(2), 15-22.

Ibrahimoglu N. , Unaldi I. , Samanciongle M. , \& Baglibel M. . (2013). The relationship between personality traits and learning styles: A cluster analysis. Retrieved October 1, 2018, from http://www.ajmse.leenaluna.co.jp/AJMSEPDFs/Vol.2(3)/AJMSE2013(2.3-10).pdf

Jalili S. \& Mall-Amiri B. (2015). The difference between extrovert and introvert EFL teachers' classroom management.Theory \& Practice in Language Studies, 5(4), 826836. http://dx.doi.org/10.17507/tpls.0504.19

Kamarulzam, W. (2012). Critical review on effect of personality on learning styles. In Proceedings of the $2^{\text {nd }}$ International Conference on Arts, Social Science and Technology, Penang Malaysia, 3rd -5th March.

Kendra C. (2016). Overview of VARK learning styles: Which learning style do you have? Retrieved October 1, 2018, from verywell. (https://www.verywellmind.com/vark-learning-styles-2795156).

Khan, A., Shin, H., Sanil, H., Sabil, S. (2018). Effect of personality traits and learning styles towards students' academic achievement in Johor Bahru. International Journal of Engineering and Technology, 7(2.10), 4-9. doi: 10.14419/ijet. V7i2.10.10943.

Kharb P., Samanta P. P., Jindal M., \& Singh V. (2013). The learning styles and the preferred teaching-learning strategies of first year medical students.Journal of Clinical and Diagnostic Research. Vol. 7(6), 1089-1092. doi:10.7860/JCDR/2013/5809.3090.

Kiziltepe, Z. (2014). The learning style and personality traits of undergraduate: A case at a State University in Istanbul. Anthropologists, 18(2), 591-600.

Kolb, D. A. (1976). Learning style inventory: Technical manual. Boston. Mass: McBer.

Kolb, D. A. (1984). Experiential Learning: Experience as the Source of Learning and Development. NJ: Prentice-Hall, Inc.

Komarraju M., Karau S., Schmeck R., \& Avdic A. (2011). The Big-five Personality Traits, Learning Styles, and Academic Achievement. Personality and Individual Differences, 51(4), 472-477. Retrieved October 3, 2018, from http://dx.doi.org/10.1016/j.paid.2011.04.019

Koning, B. B., Loyens, S. M. M., Rikers, R. M. J. P., Smeets, G. and Molen, H. T. (2012). Generation psychology: Student characteristics and academic achievement in a three-year problem-based learning Bachelor Program. Learning and Individual Differences, 22, 313-323. https://doi.org/10.1016/j.lindif.2012.01.003

Koseoglu Y. (2016). To what extent, can the big five and learning styles predict academic achievement? Journal of Education and Practice, 7(30), 43-51.

Kruck S. E. , Sendall P. , Ceccucci W. , Peslak A. , \& Hunsiger S. (2014). Does personality play a role in computer information systems course performance?Issues in Information Systems, 15(2), 383-392.

Leite, W. L., Svinicki, M., and Shi, Y. (2010). Attempted validation of the scores of the VARK: learning styles inventory with multitrait-multimethod confirmatory factor analysis models. Educational and Psychological Measurement, 70,323-339. https://dx.doi.org/10.1177/0013164409344507 
Ldpride.net (2008).Understanding your learning styles. Retrieved September 21, 2018, from http:// www.roe11.k12.il.us/GESStaff/Day3/UnderstandingYourLearningStyle s.pdf.Li, M., and Armstrong, S. J. (2015). The relationship between Kolb's experiential learning style and big five personality traits in international managers. Personality and Individual Difference, 86, 422-426. https://dx.doi.org/10.1016/j.paid.2015.07.001

Marcela, V. (2015). Learning strategy, personality traits and academic achievement of university students. Procedia-Social and Behavioral Science, 174, 3473-3478. https://dx. doi.org/10.1016/j.sbspro.2015.01.1021

MacCann, C., Fogarty, G. J. and Robert, R. D. (2012). Strategy for success in education: Time management is more important for part-time and full-time community college students. Learning and Individual Difference, 22, 618-623. http://dx.doi.org/10.1016/j.lindif.2011.09.015.

McCrae, R. R., and Costa, P. T. Jr. (1987). Validation of the five-factor model of personality across instruments and observers. Journal of Personality and Social Psychology. 52(1), 81-90. https://doi.org/10.1037/0022-3514.52.1.81

Moorman, D., and Clark, K. (2012). Student learning style and personality types: Their implications for teaching. SOTL-Commons conference paper 33 (online available: http://digitalcommons.georgiasouthern.edu.

Naserieh, F. (2009). The Relationship between perceptual learning style preferences and skill-based Learning Strategies. Unpublished Master dissertation TEFL, Department of English, Shahid Beheshti University Tehran Iran.

Nzesei, M. M. (2015). A correlation study between learning styles and academic achievement among secondary school students in Kenya. Unpublished Master dissertation, Faculty of Education, University of Nairobi.

Othman, N. \& Amiruddin M. (2010). Different perspectives of learning styles from VARK model. Procedia - Social And Behavioral Sciences, 7, 652-660. http://dx.doi.org/10.1016/j.sbspro.2010.10.088

Poroport, A. E. (2009). A Meta-analysis of five-factor model of personality and academic $\begin{array}{llll}\text { performance. } & \text { Psychological Bulletin, } & \text { 322-338. }\end{array}$ https://doi.org/10.1037/a0014996

Rashid, N. A., Taib, M. N., Lias, S., Sulaiman, N., Murat, Z. H. \& Kadir, R. S. S. A. (2012). Learners' learning style correlated to agreeableness based on EEG. Paper presented at the 2012 International Conference on Management and Education Innovation IPEDR.

Rezaeinejad M., Azizifar A. \& Gowhary, H. (2015). The Study of learning styles and its relationship with educational achievement among Iranian high school students. Procedia-Social and Behavioral Science, 199, 218-224. http://dx.doi.org/10.1016/j.sbspro.2015.07.509

Sadeghi N. , Mohd Kasim Z. , Tan B. H. , \& Abdullah F. S. (2012). Learning styles, personality types and reading comprehension performance.English Language Teaching,5(4), 116-123. http://dx.doi.org/ 10.5539/elt.v5n4p116.

Salehi A. (2010). The Study of relationship among personality factors (introversion, extroversion) of students and their effects to selecting a good teacher.ProcediaSocial and Behavioral Sciences,2(2), 4016-4020. http://dx.doi.org/10.1016/j.sbspro.2010.03.633.

Schmeck, R. R. (1983). Learning styles of college students. In R. F. Dillion and R. R. Schmeck (Eds.), Individual Differences in Cognition. New York: Academic Press Inc. 
Schmeck, R. (1988). Individual differences and learning strategies. In E. G. Weinstein, and P. Alexander (Ed). Learning and Study Strategies (pp.171-191). NY: Academic Press.

Schmit, M. J., and Ryan, A. M. (1993). The Big-five in personnel selection: Factor structure in applicant and non-applicant populations. Journal of Applied Psychology, 78(60), 966-974. https:// doi.org/10.1037//0021-9010.78.6.966

Seyal A. H. , Yeo S. M., Hj Matusin M. , Siau N. Z., \& Abdul A. (2015). Understanding students learning style and their performance in computer programming course: Evidence from Bruneian technical institution of higher learning. International Journal of Computer Theory and Engineering. 7(3), 241-247. https:// doi.org/10.7763/ijcte.2015.v7.964

Seyal, A. H., and Rahman, M. M. (2015). Understanding learning styles, attitudes and intentions in using e-Learning System: An evidence from Brunei. World Journal of Education, 53(6), 61-72. https://doi.org/10.5430/wje.v5n3p61

Shah S. \& Meisenberg G. (2012). Opinions about teaching modalities: A comparison between faculty and students. Education Research International, 1-7. http://dx.doi.org/10.1155/2012/604052

Shahri, N., Javadi, M.J., \& Esmael, M. (2012). Reviewing relationship between personality types and learning styles on psychology students in BS degree at Islamic Azad University in Tehran Central branch. International Research Journal of Applied and Basic Sciences, 3(10), 2113-2119. Online available https://www.irjabs.com/

Siaw C. L., Jagmohni S., \& Ankur, B. (2015). The relationship between learning preferences (styles and approaches) and learning outcomes among pre-clinical undergraduate medical students.BMC Medical Education, 15:44. Online available: https:// www.ncbi.nim.nih.gov. http:// dx.doi.org/ 10.1186/s12909-015-0327-0.

Siddiquei, N.L., Khalid, R. (2018). The relationship between personality traits, learning styles and academic performance of E-Learner. Open Praxis (International Council for Open and Distance Education), 10(3):1-20. https://dx. doi. org/10.5944/openpraxis.10.3.870.

Stojanovska, T-A., Malinovski, T., Vasileva, M., Jovevski, D., and Trajkovik, V. (2015). Impact of satisfaction, personality and learning Style on educational outcome in a blended learning environment. Learning and Individual Differences, 38, 127-135. : https://dx. doi.org/10.1016/j.lindif.2015.01.018

Strelau, J. (1983). A regulative theory of temperament. Australian Journal of Psychology, 35(3), 305-317. http://dx. doi.org/10.1080/00049538308258746

Strelau, J. (1988). Temperament dimensions as co-determinants of resistance to stress. In M. P. Janisse (Ed.), Individual Differences, Stress, and Health Psychology (pp. 146169). New Jersey: Springer-Verlag.

Threeton, M. D. \& Walter, R. A. (2009). The relationship between personality type and learning style: A study of automotive technology students. Journal of Industrial Teacher Education, 46(2).

The 'Big Five' Aspects of Personality. (2015). Retrieved September 17, 2018, from Free Management Books: http://www.free-managementebooks.com/faqcr/personality-02.htm

Urval R., Kamath A., Ullal S., Shenoy A., Shenoy N., \& Udupa L. (2014). Assessment of learning styles of undergraduate medical students using the VARK questionnaire and the influence of sex and academic performance.Advance Physio Education,38(3). http://dx.doi.org/10.1152/advan.00024.2014.

Whettsen, D., and Cameron, K. (1984). Developing Management Skills. London: Scott Forseman. 
Wu, C.K., and Lai, H.S. (2010). Learning style and personality type profiles of hospitality undergraduate students of Taiwan and the United States. Airity Library, 06, 111139. Online available http:/ / ge.cyut.edu.tw)

Yanadoner E. , Kiziltepe Z. , Seggie F. N. \& Sekerier S. A. (2014). The Learning styles and personality traits of undergraduates: A case at a State University in Istanbul.The Anthropologist,18(2),

591-600.

https://dx.doi.org/10.1080/09720073.2014.11891577. 